\title{
The Analysis of Workload and Need of Nurse With Wisn Method in Inpatient Room in Hospital $X$ in Yogyakarta
}

\author{
Alon Ekawati* \\ *Correspondent Author: Alonekawati7@gmail.com \\ *Master of Hospital Management, Universitas Muhammadiyah Yogyakarta, Indonesia \\ I N D E X I N G \\ Keywords: \\ Human Resources, \\ Workload; \\ WISN;

\begin{abstract}
A B S T R A C T
The success of nursing service standard of inpatient care in Hospital X is supported by the availability of human resources. Therefore, the need analysis of performer nurses based on the workload should be done. The aim of the research was to find out the workload and the need of performer nurses using WISN method. The research was qualitative in nature and the collecting technique of the number of the informant was with total sampling. The method of primary data collection was through observation and interview as well as secondary data like document study and the data of employee affair. The result of the research had WISN ration of 0.7 . It showed that if WISN ratio was $<1$, it meant that human resource in the unit has not met and did not correspond with the workload. Now, the number of human resource in inpatient room of Al-Kausar was 15 nurses whereas the need
\end{abstract} \\ according to WISN method was 21 nurses. So, the total shortage was 6 nurses.
}

Kata Kunci:

Sumber Daya Manusia;

Beban Kerja;

WISN;
Keberhasilan standar pelayanan keperawatan rawat inap di Rumah Sakit X di Yogyakara didukung oleh ketersediaan sumber daya manusia. Karena itu perlu dilakukan analisis kebutuhan tenaga perawat pelaksana berdasarkan beban kerja. Tujuan pada penelitian ini adalah untuk mengetahui beban kerja dan kebutuhan tenaga perawat pelaksana. Jenis penelitian ini adalah kulitatif dan tehnik pengambilan jumlah informan dengan total sampling. Metode pengumpulan data primer melalui observasi dan wawancara serta data sekunder berupa telaah dokumen dan data kepegawaian. Hasil penelitian ini memiliki WISN rasio 0.7, hal ini menunjukkan jika WISN rasio $<1$ artinya SDM pada unit tersebut belum mencukupi dan belum sesuai dengan beban kerja. Jumlah SDM yang berada di ruang rawat inap Al-Kausar saat ini adalah 15 perawat sedangkan kebutuhan menurut metode WISN adalah 21 perawat jadi total kekurangan adalah 6 orang perawat.

(C) 2018 JMMR. All rights reserved

\section{INTRODUCTION}

Hospital was health service institution for people, with certain characteristics obtained from the development of health science, technology advancement, and social economy life of the people that should be able to increase more quality service and affordable for the people so that the health level can be realized as high as possible. This was in apt with the definition of hospital according to Laws no. 44/ 2009 about hospital.

To increase the quality of the health service, one of the ways that should be taken into account by the leader of the hospital is it should be better and more effective in handling the human resources that the hospital has because to achieve the success of the organization, either hospital or company, human resource was one of the things that play important role. ${ }^{1}$

One of the health services in the hospital is nursing services. Nursing service is an integral part of the existing health services at hospital because almost all health services nursing services is largely a, such as the Ministry of health promotion and prevention the disease either in hospitals or other health care order is done by nurses. The quality of the existing health services in a hospital or Clinic can be affected by system services and nursing care provided by nurses as the largest component that gives its contribution or nursing services. It proves that the nursing service does have many important roles in meeting the needs of the health service, and it can be used as decision making in policy changes. ${ }^{2}$

The nurse is one of human resources owned by the hospital, so that nurses need to be noticed in the quality and amount of due service of the nursing service nursing care for 24 hours, so please note the number of nursing based on nursing workload need to be known, it is aiming to find out the needs of the quantity and quality of nursing personnel is needed so there happen workload that doesn't match that eventually impacted against the working stress of nurses and can have an impact to the safety of the patient. ${ }^{3}$ 
The decree of Minister of Health of Indonesian Republic No.81/MENKES/SK///2004 states that one of the ways to count the number of the health human resource need is by using the method of WISN (work load indicator staff need); i.e. a method of human resource calculation based on the real workload conducted by every unit in health service facility. WISN method has some strength such as very easy to operate, easy to use, technically easy to implement, comprehensive, and realistic based on the real workload. $^{4}$

Based on the previous study conducted in Hospital X in Yogyakarta in July 2017, there were some information about Hospital X, i.e. it was a hospital with type $\mathrm{C}$ that has been accredited with basic level. In addition, it had beds with capacity of 195 with BOR number of $72 \%$ and LOS of 5.6 days in 2017. The total number of the nurse was 238 and the number of beds in inpatient rooms that the hospital had was 138 with the number of inpatient performer nurses was 135 .

According to Laws No.56/ 2014 about the classification and hospital licensing, it is stated that hospital with type $\mathrm{C}$ has ratio between the number of nurse and the number of bed of 2:3 with qualification as the service in the hospital. From the result of the unstructured interview conducted in every inpatient care, there were some complaints from some nurses saying that working in adult inpatient rooms of Al- Kausar room had workload that was quite high until fair so that the head of the ward also did the work of the performer nurses. The number of bed in AlKausar ward was 20 beds with 15 nurses.

The nursing manager explained that the inpatient room of Al- Kausar inpatient room was a new ward that was officially used on April 19, 2015. The nursing manager analyzed the number of nurse needed using Depkes 2005 formula i.e. it needed 21 nurses, but the number of BORin Al-Kausar room was still low so that in the next 6 months the nursing manager analyzed the nurse needed again using Gillis formula. In Gillis formula, the number of nurse needed was 15. However, in 2017 the number of BOR was quite high until average so that the number of performer nurses needed in the room was not analyzed again. Therefore, the nursing manager suggested to count the number of nurse needed based on the workload in AlKausar inpatient room.

\section{METHOD RESEARCH}

This research was qualitative in nature and the design in this research was descriptive to find out the workload and the need of performer nurses by using WISN method in Al-Kausar inpatient room. The informant in this research was devided into 2 , i.e. the informants interviewed were 5 people consisting of nursing manager, the head of the room, and the head of the room team and the informants observed were 14 performer nurses. The instrument to measure the workload variable was by doing observation to the nursing activities divided into four, i.e. direct nursing activity, indirect nursing activity, personal activity and nonproductive activity using observation formula of time and motion study.

The instrument to count the variable of human resource need used WISN method by conducting interview and document study. The calculation of worker with WISN method consisted of five steps, i.e. choosing the human resource category, counting the available work time, workload standard, lenience standard, and counting the need of nurse. The available time work formula was as follows. $^{7}$

Available Work Time $=(\mathrm{A}(\mathrm{B}+\mathrm{C}+\mathrm{D}+\mathrm{E})) \mathrm{x} \mathrm{F}$

A was the number of work day, B was annual leave, $\mathrm{C}$ was the number of education and training, $\mathrm{D}$ was national holiday, $\mathrm{E}$ was work absence, and $\mathrm{F}$ was the number of work time. Workload standard was composed based on the time average needed for one activity and available work time in a year.

The Standard Workload is obtained from the available work time divided by the average time used to complete main activities

\section{Available Work Time Average time}

Calculating the lenience factors aimed at finding out the time to finish activity beyond the main activity. Meanwhile, the formula was as follows: As for the formula standard allowence:

\section{Average time Looseness factor Available Work Time}

The last step was counting the need of nurse with formula:

\section{Quantity Of Principal Activities + Standard allowances Standard workload.}

The quantity of the main activity was the number of main activity done in a year multiplied by the time needed to do the activity. The calculation result of the need of worker with WISN method would be compared to the available worker so that WISN ratio would be obtained.

\section{RESULTS AND DISCUSSION}

The observation result of workload analysis of the research towards the nurse activity category, that was the most often done in Al-Kausar inpatient room for 7 days was 
that the indirect nursing activity was 5,321 minutes or $53.4 \%$ and the direct nursing activity was 2,338 minutes or $23.5 \%$, the nonproductive activity was 1,838 minutes or $18.4 \%$ and personal activity was 468 minutes or $4.7 \%$. So, the workload category of performer nurses in Al-Kausar inpatient room was fair number category (76.9\%) consisting of indirect nursing main activity which was 5,321 minutes or $53.4 \%$ and the direct nursing main activity which was 2,338 minutes or $23.5 \%$.

There are five steps to calculate the number of performer nursess by using WISN method which is to determine the work unit observed. In this research, the unit under observation were the Al-Kausar inpatient wards. Total working time available for one year is 1,982.19 hours/year or 118,931.4 minutes/year consisting of (A) 6 working days, (B) 12 days annual leave, (C) 20 hours training education, (D) 16 national holidays, (E) no number of days for work absence, and $(\mathrm{F})$ is 7 hours working time of the nurse. The standard allowance for meeting activities within 1 year is 0.183 . The result of calculation of the need of the performer nursess based on the quantity of activity and workload standard in the Al-Kausar inpatient ward in nursing service unit at the hospital $\mathrm{X}$ in Yogyakarta is as follows:

Table 1. Shows the Calculation of the Number of Performer Nursess by Using WISN

\begin{tabular}{|c|c|c|c|c|}
\hline No & Nursing Activities & $\begin{array}{c}\text { Quantity Of } \\
\text { Principal Activities }\end{array}$ & $\begin{array}{c}\text { The Standard } \\
\text { Workload }\end{array}$ & Human Resource Needs \\
\hline 1 & Writing Nursing Care & 86272 & 8495.07 & 10.16 \\
\hline 3 & Complete Al-Kes & 14154 & 39643.67 & 0.36 \\
\hline 4 & Visit The Doctor & 7414 & 19821.83 & 0.37 \\
\hline 7 & Returns A Drug & 3370 & 19821.83 & 0.17 \\
\hline 8 & To the Pharmacy & 5392 & 16990.14 & 0.32 \\
\hline 9 & Organize your medication into the lockers & 3033 & 118931 & 0.03 \\
\hline 10 & Call and receive phone calls & 5392 & 118931 & 0.05 \\
\hline 14 & Washing the instrument & 4044 & 9910.92 & 0.41 \\
\hline 15 & To radiology & 4381 & 11893.1 & 0.37 \\
\hline 16 & Take the patient for surgery & 1488 & 11893.1 & 0.13 \\
\hline 17 & Pick up the patien from surgery & 3936 & 10811.91 & 0.36 \\
\hline 18 & Take the patient Hemodialisa & 1920 & 8495.07 & 0.23 \\
\hline 19 & Pick up the patient hemodialisa & 1344 & 8495.07 & 0.16 \\
\hline 20 & Accepting new patients & 2022 & 29732.75 & 0.07 \\
\hline 21 & Decubitus mattresses drying & 144 & 39643.67 & 0.00 \\
\hline 22 & Take the patient home & 4704 & 9148.54 & 0.51 \\
\hline 29 & Patient \& family communication & 13817 & 59465.50 & 0.23 \\
\hline 30 & Give the injection & 12469 & 59465.50 & 0.21 \\
\hline 31 & Install a drip & 1632 & 14866.38 & 0.11 \\
\hline 32 & Dresing infusion & 480 & 23786.20 & 0.02 \\
\hline 33 & Justify an infusion & 2022 & 39643.67 & 0.05 \\
\hline 34 & Replace the plabot infusion & 4718 & 118931 & 0.04 \\
\hline 35 & Up infusion & 1776 & 39643.67 & 0.04 \\
\hline 36 & Install The NGT & 384 & 14866.38 & 0.03 \\
\hline 37 & Paint feeding via NGT & 1248 & 13214.56 & 0.09 \\
\hline 38 & Sacsen & 1152 & 14866.38 & 0.08 \\
\hline 39 & Wound care & 3408 & 6607.28 & 0.52 \\
\hline
\end{tabular}


Table 1. (Continued) Shows the Calculation of the Number of Performer Nursess by Using WISN

\begin{tabular}{lllll}
\hline No & \multicolumn{1}{c}{ Nursing Activities } & $\begin{array}{c}\text { Quantity Of } \\
\text { Principal Activities }\end{array}$ & $\begin{array}{c}\text { The Standard } \\
\text { Workload }\end{array}$ & Human Resource Needs \\
\hline 40 & Replaces pampers & 1008 & 10811.91 & 0.09 \\
41 & Replace the patient's clothes & 384 & 29732.75 & 0.01 \\
42 & Install the decubitus mattress & 672 & 16990.14 & 0.04 \\
43 & Give O2 & 192 & 59465.50 & 0.00 \\
44 & Blood Tranfusi & 144 & 39643.67 & 0.00 \\
45 & Positioning the patient post operation & 864 & 29732.75 & 0.03 \\
46 & Nebulizer & 2208 & 13214.56 & 0.17 \\
47 & Vital sign & 21905 & 29732.75 & 0.74 \\
48 & Health education new patient & 2352 & 23786.20 & 0.10 \\
49 & Health education patients home & 3552 & 23786.20 & 0.15 \\
50 & The fasting patient education & 864 & 19821.83 & 0.04 \\
51 & Bed making & 1824 & 19821.83 & 0.09 \\
52 & Provide a remedy via NGT & 432 & 39643.67 & 0.01 \\
53 & Giving oral obaat & 864 & 59465.50 & 0.01 \\
54 & Sets the line and kasa & 528 & 10811.91 & 0.05 \\
55 & Check GDS & 96 & 59465.50 & 0.00 \\
56 & Feeding patients & 567 & 9910.92 & 0.06 \\
57 & Health education patients afesan & 528 & 10811.91 & 0.05 \\
58 & Setting up the Rekamedis patients & 192 & 59465.50 & 0.00 \\
& Sub Total Number of Human Resources & & & $\mathbf{2 0 . 7 6}$ \\
& $\quad$ Needs & & & $\mathbf{0 1 8 3}$ \\
& $\quad$ Standard Allowances & & & $\mathbf{2 0 , 9 4 3}$ \\
& The Number of Human Resources Needs & & & \\
\hline
\end{tabular}

From table 1, shows the number of nurses implementing the calculation by using the method of WISN is 21 nurses in the inpatient room Al-Kausar was a nurse.

\section{DISCUSSION}

The objective workload analysis is a productivity activity of nurse personnels expressed in the form of proportion of working time grouped into four, namely direct nursing activities, indirect nursing activities, personal activities and non-productive activities. Workload is important to know as the basis for knowing the nurse's work capacity in order to have a balance between nursing personnel and workload (Namaganda et al., 2015). Nurses in the Al-Kausar care unit is one of the work units that cannot be separated from the workload. Nurses perform a variety of activities related to medical and non-medical nursing services that support it. The nurses work in three work shifts: morning shift, afternoon shift and night shift so that the different shift conditions can affect the difference in workload they receive. ${ }^{8}$

Nurses in outpatient Department of Al-Kausar is one of the unit of work that is inseparable from the workload. Nursing personnel doing various activities related to nursing and medical services a medical menunjangnya. The nurse workforce working in three shifts i.e. morning shift work, evening shift and night shift work shift so that different conditions can affect the workload differences. ${ }^{10}$

In this research, the result of workload observation in Al-Kausar inpatient wards for 7 days shows that the most time consuming nursing activity was indirect nursing activity of 5,321 minutes $(53.4 \%)$, then direct nursing activity of 2,338 minutes $(23.5 \%)$, non-productive activities of 1,838 minutes (18.4\%) and personal activities of 468 minutes (4.7\%). This shows that the most activities performed by nurses are indirect nursing activities. This can be caused by indirect nursing activities which require a lot of time and must be completed in accordance with the procedure.

The category of workload of performer nurses in the AlKausar inpatient wards is in moderate category $(76.9 \%)$ consisting of indirect nursing activities of 5,321 minutes $(53.4 \%)$ and direct nursing activities of 2,338 minutes (23.5\%). This is in accordance with the statement (Yudatama \& Haksama 2014), if the productive working time is $>85 \%$ then it is categorized as heavy workload; if the productive working is $75 \%-85 \%$ time, it is categorized as medium work load, and if the productive work time is $<75 \%$, it is categorized as light. ${ }^{9}$ 
According to Kepmenkes RI (Decree of Indonesian significant. This is due to equitable distribution of work that Ministry of Health) Number 81 Year 2004 related to the has not been evenly. ${ }^{12}$ preparation of provincial health human resources planning, it is stated that the method of calculating human resource needs based on WISN workload is a method of calculating the health human resource needs based on the actual workload carried out by each category of health units. In this study, the number of human resource needs with WISN method is 20.76 then added with the total standard of leeway of 0.183 . So the number of performer nursess required using the WISN method is 20,943 rounded to 21 executor nurses.

This research has WISN ratio of 0.7 . This indicates that if WISN ratio is $<1$, it means that the human resources in the unit is not sufficient and not in accordance with the work load. The number of human resources in the Al-Kausar inpatient wards are 15 people, while the requirement according to WISN formula is 21 people so the total deficiency in AlKausar inpatient wards is 6 nurses.

The results of this study have similarities with research journals entitled Nursing Personnel Planning for Rural Hospitals in Burdwan District, West Bengal, India, Using Workload Indicators of Staffing Needs conducted by Shivam (et al 2014). The result of the study has WISN a ratio of 0.35 for the entire district area, which means that only $35 \%$ of the required nurses are available or it is lack of $65 \%$. The aims of this research is to know the quantity and quality requirement of the nurses needed so that there is no unsuitable work load which ultimately affects the decrease of work productivity of the nurse because it can cause the nurses work stress and can affect the patient's safety. Thus, there is a need for staff allocation and distribution so that the workload can be handled and evenly distributed among all nursing staff in India. ${ }^{3}$

The statement is also supported by a journal entitled Analisa Kebutuhan Tenaga di Instalasi Farmasi RS Universitas Muhammadiyah Malang (Worker Requirement Analysis at Pharmacy Installation of Hospital of Universitas Muhammadiyah Malang) by Susanto (et al., 2017) which has research result of WISN ratio of $<0.4$. It means that the current number of workers is smaller than the required number of workers. The shortage of the required number of workers leads to high workload conditions, which can lead to a decrease in productivity that will trigger job stress and this will impact on patient's safety. ${ }^{11}$

Both statements are supported by a research journal entitled Beban Kerja dan Motivasi Pengaruhnya terhadap Kinerja Karyawan pada PT. Bank Tabungan Negara TBK Cabang Manado (Workload and Motivation Influence on Employee Performance at PT. Bank Tabungan Negara TBK Manado Branch) conducted by Sitepu (2013). The study states that there is influence of workload on the performance but not
This study also has similarity of WISN ratio with research entitled Medical Gap Analysis in Staffing Using Workload Indicators of Staffing Need Method in A Tertiary Care Teaching Hospital conducted by Satish (2015) which has a WISN ratio of $<0.8$. It consists of current EOT Staff at the institute which includes 4 Anesthesiologists and 11 nurses. WISN ratios in both groups are higher than 1 . It can be concluded that the workload pressure in daily work is high in both anesthesia and surgery nurses. So it takes 1 Anesthesiologist and 7 nurses. Therefore, the need for anesthesia worker, according to WISN ratio, is 5 people and the requirement of nurse in surgery room is 18 nurses. The analysis of the nurses' needs using the WISN method can be used in all health facilities and all types of health staff aimed at knowing the number of staff needs based on the workload as the distribution of health personnel and the results of WISN Ratio which can be used as decision making. ${ }^{1}$

\section{CONCLUSION}

This research shows medium category work load that is $76.9 \%$. The amount of working time is $118,931.4$ minutes for one year, the amount of free time is 0.183 . The required number of nurse personnel according to WISN method is 21 nurses. The number of nurses available is 15 nurses. So in the Al-Kausar inpatient ward has a nurse shortage of 6 nurses with WISN Ratio 0.7.

\section{SUGGESTION}

For PKU Muhammadiyah Hospital In Bantul: Reevaluating the workload in the inpatient room AlKausar PKU Hospital in Bantul. Re-evaluating the principal activities of the nurse in accordance with SOP due to several activities of non nursing performed by a nurse as decubitus mattresses, washing drying instrument, setting the line and gauze, and these activities require a lot of time. It is recommended for the hospital to regulate the duties and functions of the nurse in accordance with the SOP because there are some non-nursing activities which are still conducted by the nurse such as decubitus mattress drying, instrument washing, and line and gauze arrangement. In addition, those activities takes a lot of time.

Research results can be used as consideration and evaluation of the hospital management to take the policy setandar the workload of nurses in inpatient space gradually. For Other Researchers: Should conduct research of its kind yet in different units. Should 
classify the dependence of the mobilization of patients and disease characteristics of the patients seen as a measurement of the workload. Limitations of researchers are only capable of observing one nurse and one observer $1: 1$. Researchers are only able to perform observations of nursing activities for 7 days.

\section{REFERENCE}

1. Satish, S.N., 2015. Gap Analysis in Staffing Using Workload Indicators of Staffing Need Method in A Tertiary Care Teaching Hospital. Journal Human Resources for Health, (2277), pp.376-377.

2. Sousa, Y.G. De et al., 2016. Work Loads of Nursing Professionals in Hospital Services for Mental Health: an Integrative Review. Journal of Health, Population and Nutrition, pp.1-9.

3. Shivam, S. et al., 2014. Nursing Personnel Planning for Rural Hospitals in Burdwan District, West Bengal, India, Using Workload Indicators of Staffing Needs. Journal of Health, Population and Nutrition, 32(4), pp.658-664.

4. Departeman Kesehatan RI (2004). Surat Keputusan Mentri Kesehatan No.81/MENKES/SK/I/2004 tentang Penyusunan Perencanaan Sumber Daya Manusia Kesehatan di Tingkat Propinsi. Kabupaten/Kota serta Rumah Sakit. Departemen Kesehatan Republik Indonesia, Jakarta.

5. Undang-Undang Republik Indonesia Nomor 44 Tahun 2009 Tentang Rumah Sakit

6. Undang-Undang RI Nomor 2014 Tentang Keperawatan

7. WHO, 2010. WISN Workload Indicator Staff Of Staffing Need. , pp.1-56.

8. Namaganda, G. et al., 2015. Making the transition to workload-based staffing: using the Workload Indicators of Staffing Need method in Uganda. Journal Human Resources for Health, pp.1-11. Available at: http://dx.doi.org/10.1186/s12960-0150066-7.

9. Yudatama, R. \& Haksama, S., 2014. Beban Kerja Subjektif Perawat Intensive Care Unit. Public Health of Indonesia, 2(September), pp.141-148.

10. Julia, P., Rambe, A.J.M. \& Wahyuni, D., 2014. Dengan Menggunakan Metode Workload Indicator Staff Need ( WISN ) dan Work Sampling. Public Health of Indonesia, 5(2), pp.22-25.
11. Susanto, N.A., Mansur, M. \& Djauhari, T., 2017. Analisis Kebutuhan Tenaga di Instalasi Farmasi RS Universitas Muhammadiyah Malang Tahun 2016. Public Health of Indonesia, 6(2), pp.82-90.

12. Sitepu, A.T., 2015. Beban Kerja dan Motivasi PengaruhnyaTerhadap Kinerja Karyawan pada PT. Bank Tabungan Negara TBK Cabang Manado. , 1(4), pp.1123-1133.

13. Burmen, B., Owuor, N. \& Mitei, P., 2017. An assessment of staffing needs at a HIV clinic in a Western Kenya using the WHO workload indicators of staffing need WISN ,. Journal Human Resources for Health, pp.1-8. Available at: http://dx.doi.org/10.1186/s12960-017-0186-3.

14. Giammona, S. et al., 2016. Original Paper Nursing Workload and Staff Allocation in an Italian Hospital: A Quality Improvement Initiative Based on Nursing Care Score. Journal Applied Nursing Research, 7(2), pp.420-427.

15. Kuntoro, Agus, (2012). Buku Ajar Manajemen Keperawatan, Penerbit : Mulia Medika, Yogyakarta.

16. Mardiyah, Qamariyah, Lailatul, Aziz, A.A., 2015. Pemberdayaan Guru Madrasah Ibtidaiyah Melalu Tranformasi Manajemen Mutu Suber Daya Manusia (SDM) Guna Meningkatkan Mutu Madrasah SeKecamatan di Kabupaten Jombang. , pp.1-24.

17. Mcquide, P.A. \& Forster, N., 2015. Applying the workload indicators of staffing need ( WISN ) method in Namibia : challenges and implications for human resources for health policy. Journal Human Resources for Health.

18. Mugisha, J.F. \& Namaganda, G., 2014. Using The Workload Indicator Of Staffing Needs ( WISN ) Methodology To Assess Work Pressure Among The Nursing Staff Of Lacor Hospital Introduction. Health Policy and Development, 6(1), pp.1-15.

19. Napirah, M.R. \& Sulistiani, A.O., 2015. Analysis of The Optimal Number of Staff Needed Using Workload Indicator of Staffing Needed (WISN) Method in Laboratory Unit of Public Hospital Atapura Palu. Public Health of Indonesia, 1(1), pp.18.

20. Naznin, E. et al., 2013. Human Resource Assessment for Scaling up VL Active Case Detection in Bangladesh, India and Nepal. Journal Human 
Resources for Health, 18(6), pp.734-742.

21. Oetelaar, W.F.J.M. Van Den et al., 2016. Balancing nurses ' workload in hospital wards : study protocol of developing a method to manage workload. Journal Human Resources for Health, pp.1-11.

22. Olthof, M. et al., 2018. Actual and perceived nursing workload and the complexity of patients with total hip arthroplasty. Journal Applied Nursing Research, 39(November 2016), pp.195-199. Available at: https://doi.org/10.1016/j.apnr.2017.11.023.

23. Prihadini, frieda ayu, 2012. Analisa Perhitungan Kebutuhan Tenaga Perawat di Ruang Rawat Inap Cattleya B Rumah Sakit Umum Bhakti Yudha tahun 2012. universitas indonesia.

24. Purnomo, H., 2015. Workload Analysis For Determining The Number Of Employees at Banking Complanies. Public Health of Indonesia, pp.20682076.

25. Qiu, J. \& Helbig, R., 2015. Body Posture as an Indicator of Workload in Mental Work. Human Factors: The Journal of the Human Factors and Ergonomics Society, 54(4), pp.626-635.

26. Romadhoni, D.R. \& Pudjirahardjo, J.W., 2016. Beban kerja obyektif tenaga perawat di pelayanan rawat inap rumah sakit. Public Health of Indonesia,
4, pp.57-66.

27. Ross, C., Rogers, C. \& King, C., 2018. Safety Culture and an Invisible Nursing Workload. Journal Applied Nursing Research. Available at: http://dx.doi.org/10.1016/j.colegn.2018.02.002.

28. Shieh, S. et al., 2016. Taiwanese Journal of Obstetrics \& Gynecology Increased low back pain risk in nurses with high workload for patient care : A questionnaire survey. Taiwanese Journal of Obstetrics \& Gynecology, 55(4), pp.525-529. Available at: http://dx.doi.org/10.1016/j.tjog.2016.06.013.

29. Tabatabaee, S.S. et al., 2017. Nurse Staffing Norm in Iran Hospitals : What Features Should be Included for Success. Journal Human Resources for Health.

30. Ui, F.K.M., 2012. Analisis perhitungan..., Frieda Ayu Prihadini, FKM UI, 2012.

31. Wahyuningsih, H., 2014. Analisis Kebutuhan Tenaga Perawat Pelaksana dengan Metode Workload Indicator Staff Need (WISN) di Ruang Rawat Inap Flamboyan Krakatau Medika Hospital Tahun 2014. Universitas Indonesia.

32. Yang, K., Desentralisasi, D.I. \& Pengantar, K., 2009. Perlengkapan kerja wisn. 